\title{
Current Trends in ELT and Affordances of the Inverted CLIL
}

\author{
Approach \\ Kyria Rebeca Finardi ${ }^{1 *}$ \\ ${ }^{1}$ Federal University of Espirito Santo, Vitoria, Brazil \\ *Kyria Rebeca Finardi, E-mail: kyria.finardi@gmail.com
}

\begin{abstract}
The aim of the study is to review current trends in English Language Teaching (ELT) technologies and methodologies to analyze affordances of an approach proposed by Finardi (in press) and called the Inverted CLIL approach. With that aim, the study reviews ELT technologies and methodologies in general and the Content and Language Integrated Learning (CLIL) approach with the use of Massive Online Open Courses (MOOCs) and the Inverted Classroom approach in particular. A teaching project based on the Inverted CLIL approach to teach Sustainability through English as a foreign language is elaborated as an example. Results of the study suggest that technologies have a crucial role in language teaching and should be critically incorporated in ELT methodologies. Moreover, the analysis of the Inverted CLIL approach suggests that it represents a relevant alternative for ELT and a good example of the incorporation of technology in current ELT methodologies.
\end{abstract}

\section{Keywords}

technologies and ELT methodologies, CLIL, MOOCs, inverted classroom, inverted CLIL approach

\section{Introduction}

The interconnectedness brought by technological advances, together with globalization, boosted the internationalization of higher education (e.g., Shin \& Teichler, 2014), people's mobility and language diversity. In this scenario, foreign language (L2) teaching has a very important role in 1) maintaining national cohesion (e.g., Finardi \& Csillagh, in press), 2) expanding access to information (e.g., Finardi, Prebianca, \& Momm, 2013; Finardi \& Tyler, 2015), and 3) education for life and for the social inclusion of this diversity (e.g., Ortiz \& Finardi, in press; Finardi \& Archanjo, in press).

The incorporation of technological advances in educational practicesis necessary to guarantee an educational landscape aligned with the demands of the 21 st century. Many are the challenges faced by teachers in this quest. One of these challenges is related to the lack of support and training for the incorporation of technology in education in general (e.g., Teixeira \& Finardi, 2013; Wagner, Piovesan, Passerino, De Lima, \& De Castro Lozano, 2015) and in L2 teaching/learning in particular (e.g., Finardi, Teixeira, \& Prebianca, 2014; Dias \& Pimenta, 2015). 
Given the role of English as a foreign and international language (for example, Finardi, 2014) and the need to incorporate technology in English Language Teaching (ELT) methodologies, this study has a two-fold aim, namely: to offer a review of current approaches to ELT and to analyze affordances of an approach proposed by Finardi (in press) and called the Inverted CLIL approach. More specifically, the study focuses on the integration of teaching approaches that may enable the incorporation of technologies in ELT methodologies such as the Content and Language Integrated Learning (CLIL) approach, the distance education approach used in Massive Online Open Courses (MOOCs), and blended approaches (Note 1) such as the one known as the Inverted Classroom or Flipped Classroom approach (e.g., Fadini \& Finardi, in press; Finardi, Prebianca, \& Schmitt, in press).

With that aim, the study reviews the role of technologies in ELT methodologies in general and the use of MOOCs, the Inverted Classroom and the Content and Language Integrated Learning (CLIL) approaches to ELT in particular. So as to analyze affordances of the Inverted CLIL approach (Note 2) a teaching project to teach Sustainability through English as a foreign language based on this approach is offered. The study concludes that the Inverted CLIL approach offers a relevant example of the incorporation of technology in ELT methodologies.

\section{Educational Context in the 21st Century}

Technology changed the way we express ourselves and interact with the world around us. Another effect of technology in general and of the internet and the web 2.0 (Note 3) in particular is the change in the way we produce and acquire information and knowledge, as shown in the number of Massive Online Open Courses (MOOCs) and Social Network Sites (SNSs) used in both formal and informal educational contexts.

Despite the possibilities afforded by the web 2.0 for the development of autonomy in the postmodern educational scenario and for English language teaching/learning in particular (Graddol, 2006), and in view of the widespread use of Facebook in Brazil (Note 4) coupled with the fact that much of the information online is in English (Graddol, 2006; Finardi, Prebianca, \& Momm, 2013), it would be reasonable to expect that Facebook was used as an English teaching/learning space (e.g., Rabello, 2015) too and not only as an entertainment social network. However, this is the contrary of what was found by Finardi and Porcino (2015), Finardi et al. (2013), Finardi and Veronez (2013) and Finardi and Pimentel (2013) in that context.

According to Warschauer (2002), the digital divide implies that a significant number of people are socially excluded from the access to the opportunities provided by the interconnectedness of the globalized world. Finardi, Prebianca and Momm (2013) argue that in the information society (Lévy, 1999) in which we live, some knowledge of English as an international language (for example, Finardi, 2014) and digital literacy are necessary skills to socially include people with the possibility of building social capital (Note 5) (Warschauer, 2003). Following this rationale and wishing to expand access to 
information online, Finardi and Porcino (2013) developed tasks to teach internet translation tools and reading strategies in English as a foreign language.

Educational practices are not always in tune with current trends in society, perhaps due to the the many challenges associated with the incorporation of technologies in teaching methodologies (Wagner et al., 2015), especially on the part of teachers (Prebianca, Cardoso, \& Finardi, 2014; Prebianca, Finardi, \& Cardoso, 2015) and despite some relevant efforts on the contrary (e.g., Dias \& Pimenta, 2015; Rabello, 2015).

One example of the difficulty to incorporate technologies in teaching practices is given by Teixeira and Finardi (2013) who analyzed a teacher training course for the use of technologies in traditional face-to-face classes at a university in Brazil departing from Warschauer's (2003) concept of social capital that differentiates between two types of access to technology that can lead to the formation of social capital — the limited access and the broad access. According to Warschauer (2003), the limited access to technology includes access to equipment and does not necessarily lead to the formation of social capital whereas the broad access implies the critical use of technology and can generate social capital. Teixeira and Finardi (2013) suggest that the greatest obstacle to incorporate technologies in education in Brazil is related to the broad access to technology, i.e., to the use of equipment and technologies in a critical way by teachers. So as to improve this scenario, Teixeira and Finardi (2013) suggest more investment in teacher training and education for the critical use of technologies in education.

The present study aims to partially fill in this gap by providing ELT teachers with a review of ELT methodologies and technologies so as to help them make informed and critical decisions regarding the incorporation of technologies in ELT methodologies in general and in an approach known as the Inverted CLIL (Finardi, in press) in particular. With that aim and in what follows, the study will review some ELT methodologies and the role played by the many forms of technologies used in them.

\section{ELT Methodologies and Their Technologies}

Finardi and Porcino (2014) reviewed the role of various pieces of technologies in ELT methodologies. According to them, the earliest ELT methodology was the Grammar-Translation Method (GTM) which used technology in the form of blackboard sand books, mostly to give examples of grammatically correct sentences with their translation. The GTM was followed by the Direct Method (DM) which used technologies in the form off lash cards, used to maintain the exclusive use of the target language during instruction (Leffa, 1988). Both in the GTM and in the DM, technologies served as visual support and had a peripheral role.

The Reading Approach (RA) used technology in the form of books (more didactic and less literary than in the GTM) and was in turn followed by the Audio-Lingual Method (ALM) (Borges \& Paiva, 2011) which used many technologies such as videos and audio players to produce and reproduce authentic materials. The Communicative Approach (CA) followed these methods and together with the ALM 
used the computer in the Communicative Computer Assisted Language Learning (CALL) approach (Finardi \& Porcino, 2014; Leffa, 2006; Warschauer \& Healey, 1998). In the CALL and in the CA, technology gained a more important role in ELT methodologies as it was seen as a central aid to language teaching and not as having a peripheral tool anymore. Porcino and Finardi (in press), for example, reviewed Vygotsky's social cultural theory to suggest that technology in general and the internet in particular are important "mediators" in L2 use, teaching and learning nowadays.

Richards and Rodgers (2001) point out that the crisis of the concept of method in the 1990's which was followed by the post-method era (e.g., Kumaravadivelo, 2003) deny the existence of a perfect method or approach to L2 teaching. The search for the best method seems to have been replaced by the search for more appropriate methods, proposing the use of eclectic methods and hybrid approaches (for example Brown, 2001; Finardi, 2012; Graham, 2006; Silveira \& Finardi, 2015) which use techniques and procedures of various methods and technologies, combining face-to-face instruction with virtual classroom environments.

According to Larsen-Freeman (2000) and Finardi and Porcino (2014) the CA is an umbrella term for other approaches such as the Task Based Approach (TBA), the Content and Language Integrated Learning (CLIL) approach and the Participatory Approach (PA).

The PA focuses on civic education and according to Larsen-Freeman (2000), and Finardi and Porcino (2014), it is a critical approach based on the work of Brazilian educator Paulo Freire. The PA goes beyond language goals to reach social transformation objectives (Larsen-Freeman, 2000). Since the aim of the PA is to develop civic (critical) education through language, it is important to add that in the context of the globalized world we live in, technological education in the form of digital literacy development is also necessary in this approach and so it is possible to suggest the use of technologies such as the ones used in social networks, wikis, blogs, smart phones and their applications (Paiva, in press; Leffa, 2015; Finardi \& Porcino, 2015) in this approach.

Although there is no express mention of the use of technologies in the CA or in its spring approaches such as the TBA, the CLIL or the PA, there are several possibilities to use technologies in these methodologies as suggested by Finardi (in press). Porcino and Finardi, (2015) and Porcino and Finardi (in press) suggest the use of Web quests, that according to them and others (e.g., Santos, 2013) share the same principles of the CA.

Finardi (in press), also suggests the use of MOOCs, podcasts, social networks and blogs, in the CLIL approach, besides the use of Web Quests. Bottetuit and Coutinho (2008) analyzed 483 Web Quests in English addressing the most diverse contents such as mathematics, science, physics, chemistry, and history, to name but a few. Another approach that can be used to teach different contents is the MOOC, reviewed in what follows. 


\section{MOOCs}

Internationalization of education and the search for new teaching/learning approaches that enabled a wider access to educational contents, coupled with the development of learners' autonomy and the internet paved the way to the emergence of Massive Online Open Courses (MOOCs). Some well-known MOOCs are available in platforms such as Udacity (Retrieved from https://www.udacity.com), Udemy (Retrieved from https://www.udemy.com), Coursera (Retrieved from https://www.pt.coursera.org), EdX (Retrieved from https://www.edx.org), Futurelearn (Retrieved from https://www.futurelearn.com), Iversity (Retrieved from https://www.iversity.org) and Khan Academy (Retrieved from https://www.khanacademy.org) in English, FUN (Retrieved from https://www.france-universite-numerique-mooc.fr/about) and UNOW (Retrieved from https://www.unow-mooc.org/courses/92) in French, Veduca (Retrieved from http://www.veduca.com.br) in Portuguese and Myriad (Retrieved from https://www.miriadax.net) in Spanish, not to mention the MOOCs offered by Coursera English with subtitles in other languages.

Despite the offer of MOOCs in other languages, Finardi and Tyler (2015) found that most of them (83\%) are offered in English. The dominance of English-speaking universities which offer MOOCs can also be found in the ranking of the world's top 20 universities provided each year by the Shanghai Jiao Tong University Institute and reported in Graddol (2006). This ranking shows that approximately two-thirds of the world's top 100 universities are located in English speaking-countries while the rest is located in non-English speaking universities that adopted a version of CLIL known as English Medium Instruction (EMI). Finardi and Tyler (2015), in line with Finardi, Prebianca and Momm (2013), suggest that some knowledge of English and digital literacy are necessary to participate in the globalized world scenario. Because of the characteristics of MOOCs, it is possible to use them in combination with other teaching methodologies such as the Inverted Classroom approach reviewed in the next section.

\section{Inverted Classroom Approach}

The Inverted Classroom approach was proposed by Lage, Platt and Tregial (2000) to reduce the gap between teachers' and students' expectations and styles. In this approach events that traditionally happen inside the classroom will happen outside it and vice versa. Regarding the potential of this approach to English language teaching/learning, several studies (e.g., Finardi, 2012; Prebianca, Cardoso, \& Finardi, 2014; Prebianca, Finardi, \& Cardoso, 2015) show the benefits of using hybrid methodologies which combine face-to-face classes with online instruction and which can be implemented at the level of the activity, the program or the institution (Graham, 2006).

Silveira and Finardi (2015), for example, investigated the impact of a hybrid approach to English language teaching in an intact class environment at the level of the activity in a Navy School in Brazil. They adapted tasks designed by Finardi and Porcino (2013) using online tools to develop digital literacy and translation and communication skills in English in a hybrid approach. Overall, results of their study revealed that the blended approach implemented may contribute to language development 
and digital literacy encouraging the development of learner autonomy, motivation and prolonged contact in and with the target language.

Finardi, Prebianca and Schmitt (in press) analyzed the potential ofan online English language course (My English Online-Retrieved from http://www.myenglishonline.com.br-MEO) for the Inverted Classroom approach concluding that the use of the Inverted Classroom approach in combination with the MEO course may correct the lack of support for the development of productive skills (speaking and writing) of the online course and as such, it represents a relevant teaching combination.

Fadini and Finardi (2015) reviewed web 2.0 tools for the development of the four skills in English as L2. They analyzed the potential of the following web 2.0 interfaces for ELT: the Diigo (Retrieved from https://www.diigo.com) to develop reading skills, the Voice thread (Retrieved from https://www.voicethread.com) to develop speaking skills, Podcasts/Video casts (for example, Retrieved from http://www.podcastsinenglish.com) to develop listening skills and the Pixton (Retrieved from https://www.pixton.com/uk/login/timeout?redirect=\%2Fuk\%2Fmy-home) and the Padlet (Retrieved from https://www.padlet.com) to develop writing skills. Results of their study suggest that the web 2.0 offers a myriad of under explored possibilities for ELT teaching/learning.

In another study, Fadini and Finardi (in press) analyzed the potential of four online interfaces for the Inverted Classroom approach. This time they analyzed the Edmodo (Retrieved from https://www.edmodo.com), the Socrative (Retrieved from http://www.socrative.com), the Edcanvas (Retrieved from http://www.web2teachingtools.com/edcanvas.html) and the Screencast (Retrieved from https://www.screencast.com). Results of their study suggest that these interfaces represent relevant options for the inclusion of technology in the Inverted Classroom approach for ELT.

\section{CLIL}

The Content and Language Integrated Learning (CLIL) approach aims to teach contents through a vehicular language that may be a foreign language. Conversely, it is possible to think of this approach to teach foreign languages through various contents. Finardi (in press) suggests that due to the characteristics of MOOCs and the Inverted Classroom approach, both MOOCs and the Inverted Classroom approach can be used in combination with the CLIL approach for ELT. Some efforts have already been made to include MOOCs in ELT (for example, Chen, 2015; Rybushkina \& Chuchalin, 2015).

Finardi, Silveira and Alencar (in press) analyzed the design and implementation of a CLIL teaching project carried out in regular classes to teach First Aid and Waves in English as a foreign language in a Brazilian Navy School. In their study, the English teacher worked with the Physics teacher to prepare materials. Results of their study yielded positive effects for the teaching of both the content and the language although students reported having more difficulty in the content of Waves, which is part of the Physics subject and is perceived by them as being more demanding than other subjects. Given this result, Finardi, Silveira and Alencar (in press) suggest the careful design of CLIL materials for contents 
that are more demanding so as not to overload students' cognitive capacity and so as to prevent trade off effects between the learning of contents and that of the language.

Alencar (forthcoming) analyzed the potential of CLIL as an English language teaching approach in Basic Education in Brazil where English has the status of a foreign language (for example, Finardi, 2014) and is usually taught in two classes of 50 minutes each in public schools. So as to increase the exposure to the English language without penalizing the curriculum or other disciplines, Alencar (forthcoming) suggests that English could be used in tandem with other disciplines to teach various contents, in English.

Finardi, Porcino, Fadini and Alencar (in press) studied the beliefs of Brazilian future English teachers concerning the use of CLIL and technology in English Language Teaching (ELT) in that context. Results of their study suggest that CLIL has many challenges to surpass in that country, the most important of which is the lack of English proficiency of content teachers and the lack of content proficiency of English teachers. Notwithstanding these difficulties associated with the implementation of CLIL as an approach to ELT in Brazil, the authors agree that it is a relevant possibility to teach both contents and English as a foreign language and that it is an approach which can be used in combination with technology to expand contact with the target language and contents both in and outside the class. Another study on CLIL is that of Ortiz and Finardi (in press) who analysed the role of French as a foreign language teaching through the CLIL approach as a way to develop social inclusion of immigrants and refugees in Geneva, Switzerland. Results of their study suggest that this approach develops positive attitudes towards both content and language, and in the case of the population studied, it helped to socially include the immigrants and refugees through the language as well as through the use of technology - in that case through the use of Facebook and Wasup groups to support and connect immigrants and refugees in that context.

Given the affordances of CLIL for ELT, Finardi (in press) went a step further to suggest that this approach could be used in combination with MOOCs and the Inverted Classroom approach. More specifically, the study suggested that some of the challenges to implement CLIL could be circumvented or at least reduced if CLIL was used in combination with MOOCs in the Inverted Classroom approach. So as to reflect about possibilities and limitations of this approach, coined by Finardi (in press) as the Inverted CLIL approach, the present study will analyze some of its affordances for ELT in what follows.

\section{Inverted CLIL}

Finardi (in press) suggests the teaching of contents through MOOCs in the target language, used in the Inverted Classroom approach. In her proposal, called the Inverted CLIL, the language would be taught through the content and vice versa, and class time would be dedicated to clarify doubts (about the contents or the language) and to practice oral skills in the target language. 
So as to provide an example of the Inverted CLIL approach, the present study outlines a teaching project in this approach. The teaching project described here could be used to teach the content of Sustainability in English as a foreign language using a MOOC available in the Coursera platform and adapted for the Inverted CLIL approach.

According to the information in the Coursera site, the MOOC "Introduction to Sustainability" (Retrieved from https://www.coursera.org/learn/sustainability) aims at introducing the academic approach of Sustainability, exploring how today's human societies can endure in the face of global change, ecosystem degradation and resource limitations. The course focuses on key knowledge areas of sustainability theory and practice, including population, ecosystems, global change, energy, agriculture, water, environmental economics and policy, ethics, and cultural history. The course is offered in English and subtitles are available in English, Portuguese, Vietnamese, Spanish and Chinese (simplified).

The teaching project that I am calling here "Sustainability in English" would be ideal for learners with at least an upper intermediate level of proficiency in English. Before learners were exposed to the MOOC "Introduction to Sustainability", the teacher would have to prepare a list of key content words related to the topics covered in the course (for example, population, ecosystems, global change, energy, agriculture, water, environmental economics and policy, ethics, and cultural history). The list of content words would have to be given to students, together with texts that explain the concepts and that are followed by comprehension tasks and exercises. Before assigning the tasks and exercises to be done at home, the teacher would prepare some activities on how to use internet translation tools and L2 reading strategies (for example, Finardi \& Porcino, 2013).

This teaching project could be implemented in a series of classes/phases in such a way that the first one was dedicated to the development of L2 reading strategies and the use of internet translation tools and the second was dedicated to the teaching of key content words in English. The MOOC would only be introduced in the third class/phase of the teaching project, after students had a certain level of familiarity with the key content words.

In the first phase of this teaching project, students would do the tasks and exercises at home and clarify doubts about the content words in class. Once students were equipped with the necessary vocabulary to start the MOOC, they would progress through the online course watching the videos and reading the contents at home and using the class time and teacher support to clarify doubts and to practice oral skills in English.

Since the MOOC selected provides subtitles in other languages, students could watch the videos in the MOOC at least twice, once without the subtitles (focusing on listening comprehension) and again with subtitles in their native language (focusing on form $\mathrm{x}$ meaning mappings). Productive skills could be developed in class and through speaking and writing tasks, which in turn were related to comprehension tasks (listening comprehension and reading comprehension) done at home. The 
evaluation should be made in relation to both the contents and the language and the test should resemble the types of activities and tasks done during the course, both at home and in the classroom.

As suggested by Finardi, Prebianca and Schmitt (in press) in their analysis of the potential of an English as a foreign language online course for the Inverted Classroom approach, one of the limitations of the course analyzed in their study (My English Online-MEO-Retrieved from http://www.myenglishonline.com.br) was that it did not help the development of productive skills (speaking and writing). Based on this conclusion, Finardi, Prebianca and Schmitt (in press) suggested that the course should be used in the Inverted Classroom approach whereby class time and teacher support would be used to develop productive skills whereas receptive skills (reading and listening) would be practiced at home with the online course.

Following the analysis in Finardi, Prebianca and Schmitt (in press) and based on the teaching project outlined here, the present study suggests that the Inverted CLIL approach put forward by Finardi (in press) can be used to practice language skills in the following way: productive skills would be practiced mostly in class and receptive skills would be practiced mostly at home. Moreover, the present study suggests that regardless of the content taught through the foreign language, or students' proficiency level in the foreign language, teachers prepare materials on content key words and translation techniques before assigning MOOCs to teach the contents in the foreign language.

The proposal put forward in the "Sustainability in English" teaching project suggests a stronger focus on the language in the beginning of the course (with the comprehension check and translation tasks of key content words) and a stronger emphasis on the contents in the end, with knowledge integration and transfer from both domains in a progressive way. As it is, the Inverted CLIL approach would take advantage of the possibilities afforded by MOOCs and the Inverted Classroom to teach contents and the language.

\section{Conclusion}

This study sought to review current trends in ELT technologies and methodologies to suggest that there is room to explore the Inverted CLIL approach put forward by Finardi (in press). The review of the Inverted CLIL approach showed that it may help foreign language learners to develop productive and receptive skills in a balanced way, optimizing the contact with the target language. Moreover, the study agrees with Finardi (in press) that the Inverted CLIL approach has many benefits, among which is the fact that it respects students' learning styles and times; it optimizes the use of and contact with the target language; it expands school walls by enabling learning to take place outside schools; it engages learners in more active learning, thus fostering the development of agency and autonomy; it strengthens and expands the knowledge of the target language through the contents learned and vice-versa; it is more aligned with the current demands of our society in face of technological advances and; it triggers reflection, through the transfer of knowledge from one domain to the other. Given the benefits of this approach, the study suggests that it is a relevant possibility for ELT in the current scenario.

Published by SCHOLINK INC. 


\section{References}

Alencar, J. G. C. (In press). Abordagem de Ensino de Língua Inglesa por Meio de Conteúdos e Formação de Professores: Apropriações, Possibilidades e Limitações (213f Master's Dissertation). Post Graduate Program in Education, Federal University of Espirito Santo, Vitoria, Brazil.

Barrett, B., \& Sharma, P. (2007). Blended Learning: Using technology inside and beyond the language classroom (p. 160).

Bottentuit, J. J., \& Coutinho, C. (2008). Análise das componentes e a usabilidade das webquests em língua portuguesa disponíveis na web: Um estudo exploratório. Revista deGestão da Tecnologia e Sistemas de Informação, 5(3), 453-468.

Brown, H. D. (2001). Teaching by principles: An interactive approach to language pedagogy. San Francisco: Longman.

Bruns, A. (2006). Towards Produsage: Futures for User-Led Content Production. In F. Sudweeks, H. Hrachovec, \& E. Charles (Eds.), Proceedings Cultural Attitudes towards Communication and Technology 2006 (pp. 275-284). Tartu, Estonia.

Chen, S. (2015). The research of English massive open online course based on virtual technology. Computer Modelling \& New Technologies, 19(3C), 79-82.

Coyle, D., Hood, P., \& Marsh, D. (2010). Content and language integrated learning. Ernst Klett Sprachen.

Dias, R., \& Pimenta, S. M. O. (2015). Technologies, literacies in English oral communication and teacher education: An empirical study at the university level. Revista Brasileira de Linguística Aplicada, 15(3), 711-733.

Ellis, R. (2003). Task-based language learning and teaching. Oxford: Oxford University Press.

Fadini, K., \& Finardi, K. R. (2015). Web 2.0 Tools for the L2 Class and beyond. END 2015-International Conference on Education and New Developments. World Institute for Advanced Research and Science, 1, 603-607.

Fadini, K., \& Finardi, K. R. (In press). Affordances of Web 2.0 Tools for L2 Teaching/Learning in the Flipped Classroom Format. ICERI 2015 Proceedings.

Finardi, K. R. (In press). Current trends in technologies and L2 methodologies: Affordances of CLIL and MOOCs for the Inverted Classroom. Paper submitted to Revista Veredas, November 2015.

Finardi, K. R. (2012). Technology and L2 learning: Hybridizing the curriculum. Language and Literature in the Age of Technology-III Congresso Internacional ABRAPUI Proceedings. UniversidadeFederal de Santa Catarina. Florianópolis: Universidade Federal de SantaCatarina, 1, $1-8$.

Finardi, K. R. (2014). The slaughter of Kachru's five sacred cows in Brazil and the use of English as an international language. Studies of English Language Teaching, 2, 401-411. 
Finardi, K. R., \& Archanjo, R. (In press). Reflections on internationalization of education in Brazil. Journal of International Education Research.

Finardi, K. R., \& Csillagh, V. (In press). Globalization and linguistic diversity in Switzerland: Insights from the roles of national languages and English as a foreign language. In S. Grucza, M. Olpińska, \& P. Romanowski (Eds.), Advances in Understanding Multilingualism. Warsaw Studies of Applied Linguistics, Peter Lang GmbH, International Academic Publishers, Frankfurt am Main.

Finardi, K. R., \& Pimentel, B. (2013). Crenças de professores de inglês sobre o uso do Facebook. Revista (Con) Textos Linguísticos (UFES), 7, 238-253.

Finardi, K. R., \& Porcino, M. C. (2013). Internet tools in the design of a task cycle for L2 teaching. Revista Contextos Linguísticos, 7, 273-291.

Finardi, K. R., \& Porcino, M. C. (2014). Tecnologia e Metodologia no Ensino de Inglês: Impactos da Globalização e da Internacionalização. Ilha do Desterro, 66, 239-284.

Finardi, K. R., \& Porcino, M. C. (2015). Facebook na ensinagem de inglês como língua adicional. In J. Araújo, \& V. Leffa (Orgs.), Redes sociais e ensino de língua: O que temos de aprender. Parábola Editorial, São Paulo (pp. 99-115).

Finardi, K. R., \& Porcino, M. C., Fadini, K., \& Alencar, J. G. (In press). Formação de professores de inglês para o Brasil do século XXI: Refletindo sobre as crenças de futuros professores sobre o uso de tecnologia e da metodologia CLIL no ensino de inglês. Revista Brasileira de Educação.

Finardi, K. R., \& Tyler, J. (2015). The Role of English and Technology in the Internationalization of Education: Insights from the Analysis of MOOCs. 7th International Conference on Education and New Learning Technologies Proceedings, 1, 11-18. Barcelona: IATED.

Finardi, K. R., \& Veronez, T. (2013). Beliefs on the Use of Facebook as a Communication Tool between Teachers and Students. Revista (Con) Textos Linguísticos, 7, 292-311.

Finardi, K. R., Covre, J. M., Santos, L. B., Peruzzo, S. P., \& Hildeblando J. C. A. (2013). Facebook as a tool for L2 practice. Revista (Con) Textos Linguísticos (UFES), 7, 312-325.

Finardi, K. R., Prebianca, G., \& Momm, C. (2013). Tecnologia na Educação: O caso da Internet e do Inglês como Linguagens de Inclusão. Revista Cadernos do IL, 46, 193-208.

Finardi, K. R., Prebianca, G., \& Schmitt, J. (In press). English Distance Learning: Possibilities and Limitations of MEO for the Flipped Classroom. Revista Brasileira de Linguística Aplicada. Edição.

Finardi, K. R., Silveira, N., \& Alencar, J. G. (In press). First Aid and Waves in English. Eletronic Journal of Science Education.

Finardi, K. R., Teixeira, D., Prebianca, G. V. V., \& Dos Santos, J. V. P. (2014). Information Technology and Communication in Education: Two Sides of the Coin in Brazil. International Journal of Recent Contributions from Engineering, Science \& IT, 2, 21-25.

Franco, C. P. A. (2010). Tecnologia no ensino de línguas: Do século XVI ao XXI. LetraMagna, 6, 18. 
Graddol, D. (2006). English Next: Why global English may mean the end of "English asa foreign language". In The English Company (UK) Ltd. British Council (p. 132). Retrieved from http://www.britishcouncil.org/learning-research-english-next.pdf

Graham, C. R. (2006). Blended learning systems: Definition, current trends, future directions. In C. J. Bonk, \& C. R. Graham (Eds.), Handbook of blended learning: Global perspectives, localdesigns (pp. 3-21). San Francisco, CA: Pfeiffer Publishing.

Kumaravadivelu, B. (2003). Beyond methods: Macrostrategies for language teaching. NewHaven, CT: Yale University Press.

Lage, M. J., Platt, G. J., \& Treglia, M. (2000). Inverting the classroom: A gateway to creating an inclusive learning environment. The Journal of Economic Education, 31(1), 30-43.

Larsen, F. D. (2000). Techniques and Principles in Language Teaching. Oxford: O.U.P.

Leffa, V. J. (1988). Metodologia do ensino de línguas. In H. I. Bohn, \& P. Vandresen (Eds.), Tópicos em linguística aplicada: O ensino de línguas estrangeiras (pp. 211-236). Florianópolis: Ed.da UFSC.

Leffa, V. J. (2006). Aprendizagens de línguas mediada por computador. In V. J. LEFFA (org.), Pesquisa em Linguística Aplicada: Temas e métodos (pp. 5-30). Pelotas: Educat.

Leffa, V. J. (2015). Redes sociais: Ensinando línguas como antigamente. In J. Araújo, \& V. J. Leffa (Eds.), Redes sociais e ensino de línguas: O que temos de aprender (pp. 143-159). São Paulo: Parábola.

Lévy, P. (1999). Cibercultura. São Paulo: Editora 34.

Ortiz, R., \& Finardi, K. R. (In press). Social Inclusion and CLIL: Evidence from La Roseraie. ICERI 2015 Proceedings.

Paiva, V. L. M. O. (In press). O uso da tecnologia no ensino de línguas estrangeiras: Breve retrospectiva histórica. Retrieved from http://www.veramenezes.com/techist.pdf

Porcino, M. C., \& Finardi, K. R. (2015). Webquests para a ensinagem de inglês: Análises e contribuições. In J. B. B. Junior (Org.), Metodologia WebQuest na Educação: Teoria e práticas pedagógicas (pp. 171-202). 1ed. Rio de Janeiro: Publit Soluções Editoriais.

Porcino, M. C., \& Finardi, K. R. (In press). Ensinagem de Inglês e Letramento Digitalcrítico: Uma proposta de WebQuest. Trabalhos em Linguística Aplicada.

Prebianca, G. V. V, Vieira, M. F. V., \& Finardi, K. R. (2014). Instrução gramatical na era da tecnologia: Investigando diferentes abordagens para o ensino-aprendizagem de Inglês no Ensino Médio Integrado. Signum. Estudos de Linguagem, 17, 181-214.

Prebianca, G. V. V., Cardoso, G. L., \& Finardi, K. R. (2014). Hibridizando a Educação e o Ensino de Inglês: questões de inclusão e qualidade. Revista do GEL, 11, 47-70.

Prebianca, G. V. V., Finardi, K. R., \& Cardoso, G. L. (2015). Ensino-aprendizagem em contextos híbridos: O que pensam os alunos sobre o uso da tecnologia em aulas de inglês no Ensino Médio Integrado. Caminhos em Linguística Aplicada, 12, 95-119. 
Rabello, C. (2015). Interação e aprendizagem em Sites de Redes Sociais: Uma análise a partir das concepções sócio-históricas de Vygostky e Bakhtin. Revista Brasileira de LinguísticaAplicada, 15(3), 735-760.

Richards, J. C., \& Rodgers, T. S. (2001). Approaches and Methods in Language Teaching. Cambridge: Cambridge University Press.

Richards, J., \& Rodgers, T. S. (2014). Approaches and methods in language teaching. Cambridge: Cambridge University Press.

Rybushkina, S. V., \& Chuchalin, A. I. (2015). Integrated approach to teaching ESP based on MOOCs. 43rd Annual SEFI Conference June 29-July 2, 2015 Orléans, France.

Santos, C. G. (2013). Reflexões a cerca do ensino baseado em tarefas como aporte teóricopara a metodologia Webquest. Revista (Con)textos Linguísticos, 7, 62-78.

Silveira, N., \& Finardi, K. R. (2015). Hybridizing L2 Learning: Insights from an Intact Class Experience. END 2015 Proceedings-International Conference on Education and New Developments. World Institute for Advanced Research and Science, 1, 593-597.

Teixeira, D., \& Finardi, K. R. (2013). Tics no ensino presencial: Evidências de um curso de formação continuada na Universidade Federal do Espírito Santo. Revista (Con)textosLinguísticos, 7, 79-96.

Wagner, R., Piovesan, S., Passerino, L., De Lima, J. V., \& De Castro Lozano, C. (2015). MOOCs of Inclusive Technology in Teacher Education for Vocational Education. Creative Education, 6, 1832-1840. Retrieved from http://www.scirp.org/journal/PaperInformation.aspx?paperID=60242

Warschauer, M. (2003). Social capital and access. Universal access in the Information Society, 2(4), 315-330.

Warschauer, M. (2012). Reconceptualizing the digital divide. First Monday, 7(7). Retrieved from http://www.firstmonday.org/ojs/index.php/fm/article/ view/967/888.\#w4

Warschauer, M., \& Healey, D. (1998). Computers and language learning: An overview. Language teaching, 31(2), 57-71.

\section{Notes}

Note 1. According to Barret and Sharma (2007), blended approaches combine traditional, face-to-face instruction with virtual learning environments.

Note 2. According to Finardi (in press), the Inverted CLIL approach combines the use of CLIL with MOOCs in the Inverted Classroom approach.

Note 3. The web 2.0 increased the possibilities for access and production of information online. See Bruns (2006) for the concept of produsage.

Note 4. Brazil was called the capital of social media in the world by the Wall Street Journal and Forbes Magazine in 2013.

Note 5. Warschauer (2003) defines social capital as the individuals' ability to generate benefits by means or their relationships in social practices. 